\title{
Cell Replication and Angiogenesis in Central Nervous System Tumors and Their Relationship with the Expression of Tissue Prolactin and Hyperprolactinemia
}

\author{
Denise M. D. Abech, Júlia F. S. Pereira-Lima, Carolina G. S. Leães, Rosalva T. Meurer, \\ Lígia M. Barbosa-Coutinho, Nelson P. Ferreira, Miriam C. Oliveira ${ }^{*}$ \\ Center for Neuroendocrinology, Universidade Federal de Ciências da Saúde de Porto Alegre (UFCSPA), Porto Alegre, Brazil. \\ Email: ${ }^{*}$ mco@portoweb.com.br
}

Received April 19 ${ }^{\text {th }}$ 2012; revised May 11 ${ }^{\text {th }}, 2012$; accepted May 24 ${ }^{\text {th }}, 2012$

\begin{abstract}
This study aimed to assess the effect of intracellular prolactin (ICPRL) and hyperprolactinemia on cell replication, using an immunohistochemical (IHC) technique for Ki-67 and Mcm-2, and angiogenesis, using IHC for endoglin CD-105, in central nervous system (CNS) tumors. This cross-sectional study included 79 cases of surgically excised primary CNS tumors of neuroepithelial origin (41.8\% of all cases: $10.2 \%$ astrocytomas, $24 \%$ glioblastomas and $7.6 \%$ oligodendrogliomas) and meningeal origin (58.2\% of all cases). Ki-67 and Mcm-2 indexes were calculated as a percentage of marked cells. The medians for Ki-67 and Mcm-2 indexes were significantly lower in meningiomas than in glioblastomas ( $\mathrm{p}<0.001$ for Ki-67 and $\mathrm{p}<0.001$ for Mcm-2) and oligodendrogliomas ( $<0.001$ for Ki-67 and $\mathrm{p}=0.02$ for Mcm-2). A good correlation was observed between the Ki-67 and Mcm-2 $\left(r_{S}=0.60\right)$ replication markers. There were no significant differences in vascular density between the different histological types. Immunohistochemistry for ICPRL was positive in $45.6 \%$ of the tumors. Serum prolactin (PRL) was elevated in $30.6 \%$ of the cases. Multiple regression analysis revealed no important correlation of ICPRL and serum PRL on Ki-67 and Mcm-2 indexes or vascular density. The analysis of the combined impact of ICPRL and serum PRL variables revealed a trend towards an increase in microvessel density in tumor tissue and a significant increase in cell replication markers $(\mathrm{p}=0.009$ for Ki-67 and $\mathrm{p}=$ 0.05 for Mcm-2). PRL in tumor tissue may be one of the modulating factors of cell proliferation in the CNS.
\end{abstract}

Keywords: Ki-67 Antigen; Mcm-2 Protein; Human; Endoglin Protein; Human; Prolactin; Central Nervous System Tumors

\section{Introduction}

Prolactin (PRL) was originally identified as a neuroendocrine hormone of an exclusively pituitary origin, but its presence and secretion have been recently described in other tissues [1,2]. The main extrapituitary sites of PRL production are the decidua, mammary tissue, Tlymphocytes, brain and endometrium [3,4]. Likewise, PRL receptor (PRL-R) has already been found in the hypothalamus, choroid plexus and lymphocytes [3], as well as in prostate and breast tumors and in some cases of central nervous system (CNS) tumors [5-8].

More than 300 different organic functions have been reported for PRL in different tissues [4]. At the cellular level, PRL has mitogenic, antiapoptotic, morphogenic, secretory activity and angiogenesis modulation effects [5,9].

The association between PRL and breast cancer risk

\footnotetext{
"Corresponding author.
}

has been described by several authors [10-12], and the expression of PRL and PRL-R has also been detected in prostate cancers [13], where it has a positive correlation with the histological degree of the tumor [14]. Evidence suggests that PRL stimulates cell proliferation, increasing motility and modulating neovascularization in some tumor strains $[5,13]$. The role of PRL in the CNS is uncertain, although its mitogenic activity in astrocytes [15] and its proliferative effect in meningioma $[16,17]$ and glioblastoma [18] cultured-cells have previously been described.

A recent study demonstrated the presence of PRL and hyperprolactinemia in a series of CNS tumors [8]. Therefore, this study evaluated the possible association between intracellular PRL (ICPRL) and elevated serum PRL with cell proliferation, assessed using Ki-67 antigens and the minichromosome maintenance protein 2 (Mcm-2), and with angiogenesis, assessed using endoglin 
(CD-105).

\section{Materials and Methods}

This cross-sectional study included 79 cases of primary CNS tumors of neuroepithelial (41.8\%) and meningeal (58.2\%) origin that were surgically excised at Hospital São José at Irmandade Santa Casa de Misericórdia de Porto Alegre (ISCMPA), Brazil, over a period of 40 months. Patient age ranged from 15 to 86 years (mean age $=55.6$ years) and $67 \%$ were women. The neuroepithelial tumors were distributed as follows: astrocytomas (10.2\%), glioblastomas (24\%) and oligodendrogliomas (7.6\%). The classification and grading of the tumors according to the World Health Organization (WHO) criteria [19] is shown in Table 1.

This study was approved by the Research Ethics Committee of Universidade Federal de Ciências da Saúde de Porto Alegre (UFCSPA). All patients signed an informed consent form, and the authors signed a term of confidentiality.

Before the surgery, patients were asked about exposure to medications that potentially increase serum PRL levels, and an affirmative answer was considered as an exclusion criterion, as well as elevated levels of thyroidstimulating hormone (TSH). One day before the procedure, serum PRL and TSH were measured by an automated direct chemiluminometric assay (Chiron Diagnostics Corp., East Walpole, MA). Prolactin levels above the

Table 1. Histological classification of tumors according to the WHO criteria*.

\begin{tabular}{|c|c|c|}
\hline Histological type & $\mathbf{n}$ & Grade \\
\hline \multicolumn{3}{|l|}{ Meningiomas } \\
\hline Meningothelial & 11 & I \\
\hline Fibroblastic & 9 & I \\
\hline Transitional & 9 & I \\
\hline Psammomatous & 5 & I \\
\hline Angiomatous & 6 & I \\
\hline Microcystic & 1 & I \\
\hline Secretor & 1 & I \\
\hline Atypical & 4 & II \\
\hline \multicolumn{3}{|l|}{ Astrocytoma } \\
\hline Pilocytic & 2 & I \\
\hline Diffused & 2 & II \\
\hline Anaplastic & 4 & III \\
\hline Oligodendroglioma & 2 & II \\
\hline Anaplastic oligodendroglioma & 4 & III \\
\hline Glioblastoma & 19 & IV \\
\hline
\end{tabular}

n = number of cases; *D. N. Louis, H. Ohgaki, O. D. Wiestler, W. K. Cavenee, P. C. Burger, A. Jouvet, B. W. Scheithauer and P. Kleihues, "The 2007 WHO classification of tumours of the central nervous system," Acta Neuropathologica, Vol. 114, No. 2, 2007, pp. 97-109. reference were considered hyperprolactinemia. The reference values for PRL were $2-17 \mathrm{ng} / \mathrm{ml}$ for men and 3 $29 \mathrm{ng} / \mathrm{ml}$ for women and $0.3-4.7 \mathrm{mIU} / \mathrm{L}$ for TSH.

All patients were operated on by the same neurosurgeon. After routine histopathological exam, a sample of the surgical specimen embedded in paraffin was cut (3 $\mu \mathrm{m}$ microtome) and prepared for immunohistochemistry. The same pathologist examined all slides to confirm the diagnosis and determine tumor histological type and grade according to the WHO criteria [19].

The streptavidin-biotin-peroxidase method was used to detect Ki-67 and Mcm-2 proteins, ICPRL and endoglin (CD-105). Primary antibodies used were anti-Ki-67 (MIB1, Dakocytomation, Glostrup, Denmark; dilution 1/150), anti-Mcm-2 (CRCT2.1, Novocastra, Newcastle, United Kingdom; dilution 1/30), anti-CD-105 (4G11, Novocastra, Newcastle, United Kingdom; dilution 1/50) and antiProlactin (polyclonal, Dakocytomation, Glostrup, Denmark; ready for use). Antigen recovery for Mcm-2 and CD-105 antibodies was conducted using tris-EDTA $(\mathrm{pH}$ = 9.0) for 40 minutes, and for Ki-67, sodium citrate $(\mathrm{pH}$ $=6.0$ ) for 30 minutes. Antigen recovery was not performed for ICPRL. Endogen peroxidase activity was blocked using hydrogen peroxide and non-specific proteins with bovine albumin. The antigen-antibody connection was visualized using diaminobenzidine (DAB). Palatine tonsil was used as positive control for the antiKi-67, anti-Mcm-2 and anti-CD-105, and prolactinoma tissue for anti-Prolactin (Figure 1). The same slices without primary antibody were used as negative controls.

Ki-67 and Mcm-2 indexes were calculated as a percentage of marked nuclei in about 1000 cells and expressed

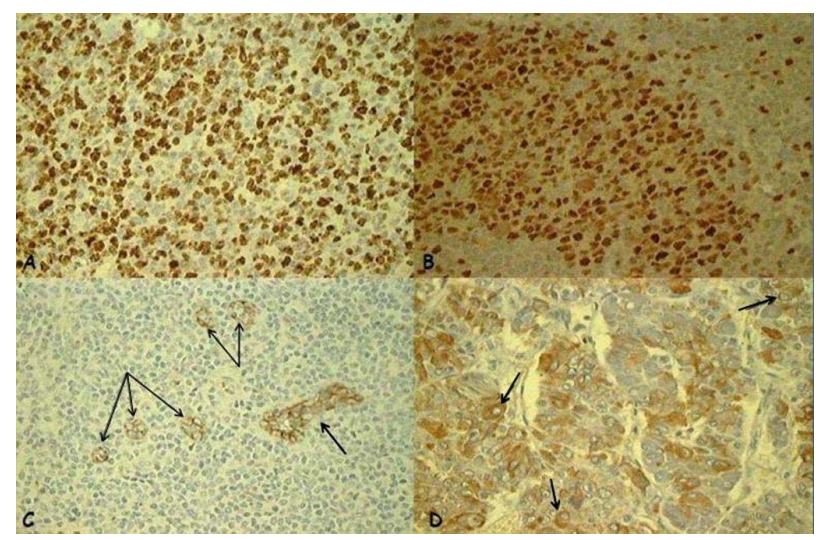

Figure 1. Positive controls: (A) Ki-67: positive nuclear expression (brown nucleus) in palatine tonsil ( $\times 40)$; (B) $\mathrm{Mcm}-$ 2: positive nuclear expression (brown nucleus) in palatine tonsil $(\times 40)$; (C) CD-105/endoglin: positive expression in vascular endothelial cells (arrow) in palatine tonsil $(\times 40)$; (D) Intracellular prolactin: positive cytoplasmic expression in the juxtanuclear distribution (arrow) in a prolactinoma $(\times 40)$. 
as the mean of the values found by two observers, who were blinded to the experiment $[20,21]$. To evaluate the expression of ICPRL, the unequivocal presence of at least $1 \%$ of tumor cells with clearly marked cytoplasm in 300 counted tumor cells was classified as positive $[8,22]$. Evaluation of microvascular density (MVD) using antiCD-105 was performed using the Chalkley point counting method, internationally acknowledged as the criterion standard for the evaluation of MVD [23]. The technique consists of selecting three fields of greater MVD-the so-called hotspots-which are subjectively chosen on each slide after scanning the tumor section in a microscopic field of low magnification $(\times 10)$. The Chalkley grid with 25 random points was attached to the lens of a light microscope and, at a larger magnification $(\times 200)$, directed to each hotspot so that the greatest number of grid points coincided with the endothelium or fell within the microvascular areas stained with IHC. Endothelial cells or cell groups were classified as countable microvessels. MVD CD-105 was evaluated according to the mean count of microvessels in the three hotspots, also called the Chalkley index or mean MVD. The Chalkley point count was performed by two experienced observers independently. The final MVD was the mean value of the two independent counts.

The median (minimum and maximum) values were used in the analysis of quantitative variables because of data asymmetry. The intraclass correlation coefficient (ICC) was used to analyze agreement between the two observers. The Mann-Whitney test was used to compare the Ki-67, Mcm-2, CD-105 marker values between groups with positive and negative ICPRL according to the different types of tumors. A linear regression was run on logarithmically transformed data to assess the combined effect of ICPRL and serum PRL on cell proliferation and angiogenesis markers. The level of significance was set at 5\%. Data were analyzed using the Statistical Package for the Social Sciences (SPSS) version 15.0 for Windows (SPSS Inc., Chicago, IL).

\section{Results}

There was good agreement between readings by the two observers, and ICC ranged from 0.96 to 0.99 . Figure 2 shows the unequivocal nuclear positivity of Ki-67, Mcm-2 (a,b) and vascular endothelial cells CD-105 (c) in the tumors under analysis.

Median Ki-67 indexes in meningiomas, astrocytomas, glioblastomas and oligodendrogliomas were $3.0 \%, 4.7 \%$, $10.4 \%$ and $18.6 \%$, and there was a significant difference between meningiomas and glioblastomas $(\mathrm{p}<0.001)$ and oligodendrogliomas $(\mathrm{p}<0.001)$.

Median Mcm-2 indexes were $7.2 \%, 6.8 \%, 30 \%$ and $20.4 \%$ for meningiomas, astrocytomas, glioblastomas and oligodendrogliomas, and there were significant differences between meningiomas and astrocytomas when compared to glioblastomas ( $\mathrm{p}<0.001$ and $\mathrm{p}<0.001)$ and oligodendrogliomas $(\mathrm{p}=0.02$ and $\mathrm{p}=0.05)$.

Median vascular density values were 8.1; 6.7; 9.2 and 12.8 for meningiomas, astrocytomas, glioblastomas and oligodendrogliomas, but there were no significant differences between groups.

The correlation between Ki-67 and Mcm-2 was good $\left(\mathrm{r}_{\mathrm{S}}=0.60\right)$, but only fair between vascular density and Mcm-2 ( $\left.\mathrm{r}_{\mathrm{S}}=0.39\right)$ and Ki-67 $\left(\mathrm{r}_{\mathrm{S}}=0.21\right)$.

Immunohistochemistry for ICPRL was positive in 36 (45.6\%) of the tumors. There were no significant differences between groups with and without positivity for ICPRL regarding age, sex, tumor histological type or cell proliferation and angiogenesis markers (Tables 2 and 3). Figure 3 shows the cytoplasmic immunopositivity for ICPRL in the juxtanuclear distribution.

Serum PRL samples were available from 62 of the 79 cases analyzed. Serum PRL levels ranged from 4 to 70 $\mathrm{ng} / \mathrm{ml}$, and were high in 19 cases (30.6\%). No significant differences were found in age, sex, histological type or cell proliferation and angiogenesis markers between the groups of patients with variable hyperprolactinemia and normal serum PRL (Tables 4 and 5).

When evaluated in isolation using a multiple regression model, no important effect was found for ICPRL or serum PRL on Ki-67 and Mcm-2 indexes and vascular density.

To assess the possible combined impact of ICPRL and serum PRL variables on cell replication and angiogenesis

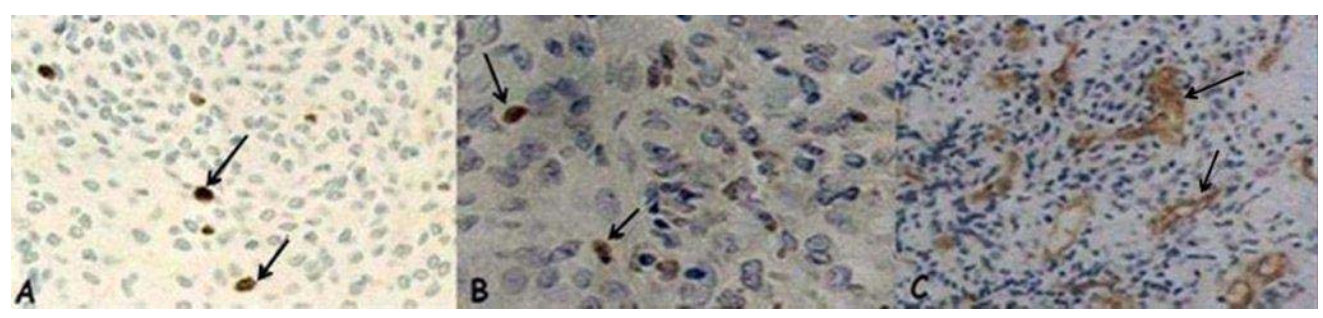

Figure 2. (A) Ki-67: positive nuclear expression (arrow) in a meningioma ( $\times 40)$; (B) Mcm-2: positive nuclear expression (arrow) in a glioblastoma ( $\times 40)$; (C) CD-105/endoglin: positive expression in vascular endothelial cells (arrow) in an anaplastic oligodendroglioma $(\times 20)$. 


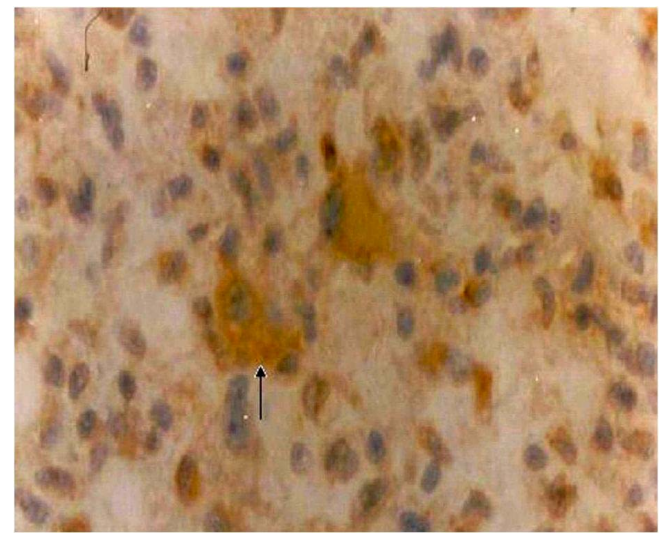

Figure 3. Intracellular prolactin: positive cytoplasmic expression in the juxtanuclear distribution (arrow) in a meningioma $(\times 40)$. markers, the 62 samples were assembled into three groups: group 1 = positive ICPRL and hyperprolactinemia; group 2 = ICPRL or hyperprolactinemia; and group 3 = negative ICPRL and normal serum PRL. This analysis of gathered groups revealed a trend towards an increase in vascular density in the presence of ICPRL and/or hyperprolactinemia, which was significant for the Ki-67 and Mcm-2 indexes (Table 6).

\section{Discussion}

The Ki-67 index, a parameter of cells in the cell cycle, has been extensively studied and validated as a good cell replication marker [24,25]. The Ki-67 index values in this series were similar to those reported in other studies [26], although higher in oligodendrogliomas when compared with the series studied by Wharton et al. [20].

Table 2. Distribution of cases according to age, sex, tumor histological type and ICPRL positivity.

\begin{tabular}{cccc}
\hline Variable & Positive ICPRL $\mathbf{n}=\mathbf{3 6}$ & Negative ICPRL $\mathbf{n}=\mathbf{4 3}$ & $\mathbf{p}^{*}$ \\
\hline Age (years) & ${ }^{\dagger}$ & $60(26-86)$ & 0.54 \\
Women & $57(15-84)$ & $33(77 \%)$ & 0.08 \\
Histological type & $20(56 \%)$ & & 0.68 \\
Meningioma & & $27(63 \%)$ & \\
Astrocytoma & $19(53 \%)$ & $4(9 \%)$ & \\
Glioblastoma & $4(11 \%)$ & $10(23 \%)$ & \\
Oligodendroglioma & $9(25 \%)$ & $2(5 \%)$ &
\end{tabular}

ICPRL = intracellular prolactin; $\mathrm{n}=$ number of cases; ${ }^{*}$ Chi-square test; ${ }^{\dagger}$ Median (minimum and maximum).

Table 3. Values for cell proliferation (Ki-67 and Mcm-2) and angiogenesis (CD-105) markers in different histological types according to positive and negative ICPRL ${ }^{*}$.

\begin{tabular}{|c|c|c|c|c|c|}
\hline Histological type & $\mathbf{n}$ & Positive ICPRL & $\mathbf{n}$ & Negative ICPRL & $\mathbf{p}^{\dagger}$ \\
\hline & & Ki-67 (\%) & & Ki-67 (\%) & \\
\hline Meningiomas & 19 & $3.5(0.8-12.9)$ & 27 & $3.0(0.9-9.8)$ & 0.47 \\
\hline Glioblastomas & 9 & $10.5(6.0-20.3)$ & 10 & $9.8(2.3-34.0)$ & 0.76 \\
\hline Oligodendrogliomas & 4 & $18.5(11.4-39.0)$ & 2 & $13.2(6.3-20.2)$ & 0.80 \\
\hline Total & & Mcm-2 (\%) & & Mcm-2 (\%) & \\
\hline Meningiomas & 19 & $8.2(3.9-14.9)$ & 27 & $6.4(3.2-11.6)$ & 0.34 \\
\hline Astrocytomas & 4 & $6.5(3.2-20.1)$ & 4 & $6.9(1.4-10.2)$ & 0.99 \\
\hline Glioblastomas & 8 & $30.0(15.8-69.9)$ & 10 & $29.5(6.1-56.8)$ & 0.72 \\
\hline Oligodendrogliomas & 4 & $16.3(2.4-41.0)$ & 2 & $31.0(22.9-39.0)$ & 0.53 \\
\hline \multirow[t]{2}{*}{ Total } & 36 & $14.3(0.8$ - 69.9) & 43 & $8.0(1.1-56.8)$ & 0.31 \\
\hline & & CD-105 & & CD-105 & \\
\hline Meningiomas & 19 & $8.7(7.2-11.5)$ & 27 & $6.7(3.2-11.5)$ & 0.11 \\
\hline Astrocytomas & 4 & $5.8(6.0-7.0)$ & 4 & $8.8(6.0-12.0)$ & 0.06 \\
\hline Glioblastomas & 8 & $9.3(7.0-8.0)$ & 10 & $8.5(6.0-11.0)$ & 0.18 \\
\hline Oligodendrogliomas & 4 & $8.5(0.0-17.0)$ & 2 & $14.8(15.0$ - 15.0) & 0.53 \\
\hline Total & 36 & $8.5(1.5-15.6)$ & 43 & $7.8(0.0-15.0)$ & 0.31 \\
\hline
\end{tabular}

ICPRL = intracellular prolactin; $\mathrm{n}=$ number of cases; ${ }^{\star}$ Data presented as median (minimum and maximum); ${ }^{\dagger}$ Mann-Whitney test. 
Table 4. Distribution of cases according to age, sex, tumor histological type and serum PRL.

\begin{tabular}{cccc}
\hline Variable & Hyperprolactinemia n = 19 & Normal serum PRL n = 43 & p* \\
\hline Age (years) $\dagger$ & $55(15-84)$ & $61(26-86)$ & 0.37 \\
Women & $13(41 \%)$ & $33(77 \%)$ & 0.14 \\
Histological type & & & 0.49 \\
Meningioma & $9(47.4 \%)$ & $26(60.5 \%)$ \\
Astrocytoma & $2(10.5 \%)$ & $5(11.6 \%)$ \\
Glioblastoma & $7(36.8 \%)$ & $8(18.6 \%)$ \\
Oligodendroglioma & $1(5.3 \%)$ & $4(9.3 \%)$ \\
\hline
\end{tabular}

$\mathrm{n}=$ number of cases; PRL= prolactin; $^{*}$ Chi-square test; ${ }^{\dagger}$ Median (minimum and maximum).

Table 5. Values for cell proliferation (Ki-67 and Mcm-2) and angiogenesis (CD-105) markers in different histological types according to serum PRL*.

\begin{tabular}{|c|c|c|c|c|c|}
\hline Histological type & $\mathbf{n}$ & Hyperprolactinemia & n & Normal PRL & $\mathbf{p}^{\dagger}$ \\
\hline & & Ki-67 (\%) & & Ki-67 (\%) & \\
\hline Meningiomas & 9 & $3.8(1.3-12.5)$ & 26 & $2.9(0.7-12.8)$ & 0.59 \\
\hline Astrocytomas & 2 & $7.6(3.0-12.3)$ & 5 & $4.0(2.6-20.2)$ & 0.85 \\
\hline Glioblastomas & 6 & $15.5(6.0-34.5)$ & 8 & $9.0(4.4-19.9)$ & 0.18 \\
\hline Oligodendrogliomas & 1 & 18.5 & 3 & $11.4(6.3-39.0)$ & 0.80 \\
\hline \multirow[t]{2}{*}{ Total } & 18 & $6.5(1.3-34.5)$ & 42 & $4.3(0.7-39.0)$ & 0.11 \\
\hline & & Mcm-2 (\%) & & Mcm-2 (\%) & \\
\hline Meningiomas & 9 & $7.6(1.1-26.0)$ & 26 & $4.5(0.8-28.4)$ & 0.67 \\
\hline Astrocytomas & 2 & $8.6(7.1-10.2)$ & 5 & $5.9(1.3-20.1)$ & 0.38 \\
\hline Glioblastomas & 7 & $34.3(19.8$ - 69.9) & 8 & $28.6(15.6$ - 42.7) & 0.23 \\
\hline Oligodendrogliomas & 1 & 14.6 & 4 & $20.4(2.4-41.0)$ & 0.53 \\
\hline \multirow[t]{2}{*}{ Total } & 19 & 10.2 (1.1 to 69.9$)$ & 43 & $8.0(0.8-42.7)$ & 0.12 \\
\hline & & CD-105 & & CD-105 & \\
\hline Meningiomas & 9 & $8.1(0.0-12.0)$ & 26 & $6.8(0.0-14.0)$ & 0.42 \\
\hline Astrocytomas & 2 & $8.7(6.0-12.0)$ & 5 & $7.4(6.0-10.0)$ & 0.57 \\
\hline Glioblastomas & 7 & $8.1(7.0-12.0)$ & 8 & $9.2(6.0-12.0)$ & 0.95 \\
\hline Oligodendrogliomas & 1 & 6.1 & 4 & $13.0(0.0-17.0)$ & 0.53 \\
\hline Total & 19 & $8.2(0.0-12.0)$ & 43 & $7.7(0.0-17.0)$ & 0.46 \\
\hline
\end{tabular}

$\mathrm{n}=$ number of cases; PRL= prolactin; ${ }^{*}$ Data presented as median (minimum and maximum); ${ }^{\dagger}$ Mann-Whitney test.

Table 6. Values for Ki-67, Mcm-2 and CD-105 markers according to positive ICPRL and Hyperprolactinemia (Group 1), positive ICPRL or Hyperprolactinemia (Group 2) and negative ICPRL and normal serum PRL (Group 3)*.

\begin{tabular}{cccccccc}
\hline Marker & $\mathbf{n}$ & $\begin{array}{c}\text { Positive ICPRL and } \\
\text { Hyperprolactinemia } \\
\text { Group 1 }\end{array}$ & $\mathbf{n}$ & $\begin{array}{c}\text { Positive ICPRL or } \\
\text { Hyperprolactinemia } \\
\text { Group 2 }\end{array}$ & $\mathbf{n}$ & $\begin{array}{c}\text { Negative ICPRL and } \\
\text { normal serum PRL } \\
\text { Group 3 }\end{array}$ & $\mathbf{p}^{\dagger}$ \\
\hline Ki-67 & 8 & $11.6(1.3-20.3)$ & 29 & $4.8(0.8-39.1)$ & 23 & $3.3(0.9-19.9)$ & $0.009^{*}$ \\
Mcm-2 & 9 & $19.9(3.9-69.9)$ & 30 & $8.5(0.8-41.0)$ & 23 & $6.6(1.1-42.8)$ & $0.05^{*}$ \\
CD-105 & 9 & $8.2(6.0-12.0)$ & 30 & $8.7(0.0-17.0)$ & 23 & $6.6(0.0-15.0)$ & 0.115 \\
\hline
\end{tabular}

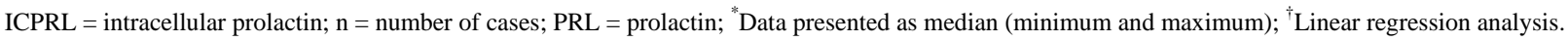


More recently, Mcm-2, a pre-replication complex essential for the replication of eukaryotic cells, has been used to assess the cell cycle [27]. The Mcm-2 index in this study showed a good correlation with the Ki-67 index, with the highest median Mcm-2 in all groups of tumors under study. This finding may be assigned to the fact that Mcm-2 can also identify cells in stage G1 to G0, whereas the Ki-67 marker can only identifies cells in G1 [28].

The tumor angiogenesis grade measured according to microvascular density has also been used as a potential prognostic marker and possible treatment target in CNS tumors [29], particularly for gliomas. In a study that evaluated angiogenesis in gliomas, Lebelt et al. [30] found a greater microvessel density in glioblastomas and a significant correlation with degrees of malignancy. Angiogenesis in oligodendrogliomas, different from in other CNS tumors, is little known. Usually considered a slowgrowing tumor, in some cases the course is more rapid and the histological features show vascular endothelial proliferation [31]. In a recent study, Netto et al. [32] found a significant difference in microvessel density between grade II and III oligodendrogliomas. In spite of not presenting statistical difference, the higher values of median vascular density in our study were found in oligodendrogliomas. Although the pattern of angiogenesis can be quite different among histological types of CNS tumors, in our series, the comparison of microvessel median densities did not reveal any significant differences between the different types of tumors of our sample.

Barresi et al. [21] found a strong correlation between histological grade, Ki-67 index and extension of tumor vascularization using the CD-105 marker in meningiomas. Our study did not confirm their results, as the correlation between replication markers and angiogenesis markers was weak.

The relationship between PRL and CNS tumors claims for attention since 1980, when the first reports of cases of hyperprolactinemia associated with meningiomas were described [33,34]. Other cases of hyperprolactinemia associated with a gangliocytoma with immunohistochemically positive PRL [35], and hyperprolactinemia and third ventricle epidermoid cyst [36], were reported. Ciccarelli et al. [7], in a series of CNS tumors found high PRL levels varying from $27 \%$ to $61.5 \%$ in the different histological subtypes. In our study, despite serum prolactin have varied from 4 to $70 \mathrm{ng} / \mathrm{ml}$ and levels of hyperprolactinemia have varied from 20 to $70 \mathrm{ng} / \mathrm{ml}$, the possibility of PRL influence could not be disregarded, since hyperprolactinemia it was found in $30.6 \%$ of all tumors.

The mainly source of PRL in the human organism is the anterior pituitary. However, there is clear evidence that several human cells/tissue physiologically express
PRL and the main extrapituitary sites described of PRL production are the decidua, mammary tissue, the prostate, the brain, the skin, T-lymphocytes and adipocytes [3,4, 37]. In this study immunohistochemistry for ICPRL was positive in $45.6 \%$ of the tumors. To the best of our knowledge literature describes just one study in which ICPRL in nervous system tumors was observed in $21 \%$ of all tumor subtypes [8]. The relationship between ICPRL and serum PRL is complex, given that 1 ) serum PRL could act in tumor cells regardless of the PRL receptor; 2) intracellular expression of PRL may reflect or not local origin; and 3) the hyperprolactinemia do not necessarily reflect the tumor tissue production.

The functional impact of extrapituitary PRL has been mainly linked to tumorigenesis [37]. There has been growing interest in the recent recognition of the prolixferative and angiogenesis action associated with the activity of PRL, an endocrine and autocrine/paracrine hormone $[9,38]$. In this sense, the interest in substances with a therapeutic potential against the proliferative action of extrapituitary PRL has grown with the evidence of tissue expression of PRL-R in $80 \%-90 \%$ of breast cancers, with greater expression in neoplastic tissue than in the tissue adjacent to the tumor [39], and the expression of PRL and activation of stat5a/b in association with tumor grade in prostate cancer [14]. In this series, the analysis of the combined impact of ICPRL and serum PRL variables revealed a trend towards an increase in microvessel density in tumor tissue and regarding replication, despite assessing different CNS tumors, histological type and grade of malignancy, we found a significant increase in cell replication markers.

To our knowledge, this is the first study to assess the effect of ICPRL and the increase in PRL serum levels on the cell cycle and angiogenesis in CNS tumors. The significant increase in Ki-67 and Mcm-2 indexes when both variables (ICPRL and hyperprolactinemia) were positive suggest that PRL modulation has an effect on cell replication in tumor tissue. Future clinical studies should investigate possible progression paths in patients with CNS tumors who have hyperprolactinemia or ICPRL in tumor cells.

\section{Acknowledgements}

We thank the Graduate Program of Universidade Federal de Ciências da Saúde de Porto Alegre (UFCSPA), Porto Alegre, Brazil; we also thank Teresinha Stein for her technical assistance.

\section{REFERENCES}

[1] A. Bachelot and N. Binart, "Reproductive Role of Prolactin,” Reproduction, Vol. 133, No. 2, 2007, pp. 361-369. 


\section{doi:10.1530/REP-06-0299}

[2] V. Goffin, N. Binart, P. Touraine and P. A. Kelly, "Prolactin: The New Biology of an Old Hormone,” Annual Review of Physiology, Vol. 64, 2002, pp. 47-67. doi:10.1146/annurev.physiol.64.081501.131049

[3] N. Ben-Jonathan, J. L. Mershon, D. L. Allen and R. W. Steinmetz, "Extrapituitary Prolactin: Distribution, Regulation, Functions, and Clinical Aspects," Endocrine Reviews, Vol. 17, No. 6, 1996, pp. 639-669.

[4] J. Harris, P. M. Stanford, S. R. Oakes and C. J. Ormandy, "Prolactin and the Prolactin Receptor: New Targets of an Old Hormone,” Annals of Medicine, Vol. 36, No. 6, 2004, pp. 414-425. doi:10.1080/07853890410033892

[5] C. V. Clevenger, P. A. Furth, S. E. Hankinson and L. A. Schuler, "The Role of Prolactin in Mammary Carcinoma,” Endocrine Reviews, Vol. 24, No. 1, 2003, pp. 127. doi:10.1210/er.2001-0036

[6] I. Leav, F. B. Merk, K. F. Lee, M. Loda, M. Mandoki, J. E. McNeal and S. M. Ho, "Prolactin Receptor Expression in the Developing Human Prostate and in Hyperplastic, Dysplastic, and Neoplastic Lesions," The American Journal of Pathology, Vol. 154, No. 3, 1999, pp. 863-870. doi:10.1016/S0002-9440(10)65333-3

[7] E. Ciccarelli, P. Razzore, D. Gaia, C. Todaro, A. Longo, M. Forni, C. Ghè, F. Camanni, G. Muccioli, G. Faccani and M. M. Lanotte, "Hyperprolactinaemia and Prolactine Binding in Benign Intracranial Tumours," Journal of Neurosurgical Sciences, Vol. 45, No. 2, 2001, pp. 70-74.

[8] C. G. Soares Leães, A. P. Filho, J. F. Pereira Lima, C. M. Dallago, R. L. Batista, L. M. Barbosa-Coutinho, N. P. Ferreira and M. da Costa Oliveira, "Hyperprolactinemia and Immunohistochemical Expression of Intracellular Prolactin and Prolactin Receptor in Primary Central Nervous System Tumors and Their Relationship with Cellular Replication,” Brain Tumor Pathology, Vol. 24, No. 2, 2007, pp. 41-46. doi:10.1007/s10014-007-0220-6

[9] N. Ben-Jonathan, K. Liby, M. McFarland and M. Zinger, "Prolactin as an Autocrine/Paracrine Growth Factor in Human Cancer," Trends in Endocrinology and Metabolism, Vol. 13, No. 6, 2002, pp. 245-250. doi:10.1016/S1043-2760(02)00603-3

[10] B. K. Vonderhaar, "Prolactin in Human Breast Cancer Development,” In: S. P. Ethier, Ed., Endocrine Oncology, Humana Press, Totowa, 2000, pp. 101-120. doi:10.1385/1-59259-223-6:101

[11] S. S. Tworoger, A. H. Eliassen, P. Sluss and S. E. Hankinson, "A Prospective Study of Plasma Prolactin Concentrations and Risk of Premenopausal and Postmenopausal Breast Cancer,” Journal of Clinical Oncology, Vol. 25, No. 12, 2007, pp. 1482-1488. doi:10.1200/JCO.2006.07.6356

[12] S. E. Hankinson, W. C. Willett, D. S. Michaud, J. E. Manson, G. A. Colditz, C. Longcope, B. Rosner and F. E. Speizer, "Plasma Prolactin Levels and Subsequent Risk of Breast Cancer in Postmenopausal Women," Journal of the National Cancer Institute, Vol. 91, No. 7, 1999, pp. 629-634. doi:10.1093/jnci/91.7.629

[13] M. T. Nevalainen, E. M. Valve, P. M. Ingleton, M. Nurmi,
P. M. Martikainen and P. L. Harkonen, "Prolactin and Prolactin Receptors Are Expressed and Functioning in Human Prostate," The Journal of Clinical Investigation, Vol. 99, No. 4, 1997, pp. 618-627. doi:10.1172/JCI119204

[14] H. Li, T. J. Ahonen, K. Alanen, J. Xie, M. J. LeBaron, T. G. Pretlow, E. L. Ealley, Y. Zhang, M. Nurmi, B. Singh, P. M. Martikainen and M. T. Nevalainen, "Activation of Signal Transducer and Activator of Transcription 5 in Human Prostate Cancer Is Associated with High Histological Grade,” Cancer Research, Vol. 64, No. 14, 2004, pp. 4774-4782. doi:10.1158/0008-5472.CAN-03-3499

[15] W. J. De Vito, W. C. Okulicz, S. Stone and C. Avakian, "Prolactin-Stimulated Mitogenesis of Cultured Astrocytes,” Endocrinology, Vol. 130, No. 5, 1992, pp. 25492556. doi:10.1210/en.130.5.2549

[16] E. Jimenez-Hakim, M. El-Azouzi and P. M. Black, “The Effect of Prolactin and Bombesin on the Growth of Meningioma-Derived Cells in Monolayer Culture,” Journal of Neuro-Oncology, Vol. 16, No. 3, 1993, pp. 185-190. doi:10.1007/BF01057032

[17] G. Muccioli, C. Ghè, G. Faccani, M. Lanotte, M. Forni and E. Ciccarelli, "Prolactin Receptors in Human Meningiomas: Characterization and Biological Role," The Journal of Endocrinology, Vol. 153, No. 3, 1997, pp. 365-371. doi:10.1677/joe.0.1530365

[18] T. Ducret, S. Boudina, B. Sorin, A. M. Vacher, I. Gourdou, D. Liquoro, J. Guerin, L. Bresson-Bepoldin and P. Vacher, "Effects of Prolactin on Intracellular Calcium Concentrations and Cell Proliferation in Human Glioma Cells,” Glia, Vol. 38, No. 3, 2002, pp. 200-214. doi:10.1002/glia.10056

[19] D. N. Louis, H. Ohgaki, O. D. Wiestler, W. K. Cavenee, P. C. Burger, A. Jouvet, B. W. Scheithauer and P. Kleihues, "The 2007 WHO Classification of Tumours of the Central Nervous System,” Acta Neuropathologica, Vol. 114, No. 2, 2007, pp. 97-109. doi:10.1007/s00401-007-0243-4

[20] S. B. Wharton, F. A. Hamilton, W. K. Chan, K. K. Chan and J. R. Anderson, "Proliferation and Cell Death in Oligodendrogliomas," Neuropathology and Applied Neurobiology, Vol. 24, No. 1, 1998, pp. 21-28.

[21] V. Barresi, S. Cerasoli, E. Vitarelli and G. Tuccari, "Density of Microvessels Positive for CD105 (Endoglin) Is Related to Prognosis in Meningiomas," Acta Neuropathologica, Vol. 114, No. 2, 2007, pp. 147-156. doi:10.1007/s00401-007-0251-4

[22] M. Pawlikowski, J. Kunert-Radek and M. Radek, "Plurihormonality of Pituitary Adenomas in Light of Immunohistochemical Studies,” Endokrynologia Polska, Vol. 61, No. 1, 2010, pp. 63-66.

[23] P. B. Vermeulen, G. Gasparini, S. B. Fox, C. Colpaert, L. P. Marson, M. Gion, J. A. Beliën, R. M. de Waal, E. Van Marck, E. Magnani, N. Weidner, A. L. Harris and L. Y. Dirix, "Second International Consensus on the Methodology and Criteria of Evaluation of Angiogenesis Quantification in Solid Human Tumours," European Journal of Cancer, Vol. 38, No. 12, 2002, pp. 1564-1579. 


\section{doi:10.1016/S0959-8049(02)00094-1}

[24] P. E. McKeever, D. A. Ross, M. S. Strawderman, J. A. Brunberg, H. S. Greenberg and L. Junck, “A Comparison of the Predictive Power for Survival in Gliomas Provided by MIB-1, Bromodeoxyuridine and Proliferating Cell Nuclear Antigen with Histopathologic and Clinical Parameters," Journal of Neuropathology and Experimental Neurology, Vol. 56, No. 7, 1997, pp. 798-805.

[25] K. Onda, R. L. Davis, M. Shibuya, C. B. Wilson and T. Hoshino, "Correlation between the Bromodeoxyuridine Labeling Index and the MIB-1 and Ki-67 Proliferating Cell Indices in Cerebral Gliomas,” Cancer, Vol. 74, No. 7, 1994, pp. 1921-1926. doi:10.1002/1097-0142(19941001)74:7<1921::AID-CNC $\underline{\mathrm{R} 2820740716>3.0 . \mathrm{CO} ; 2-9}$

[26] G. Haddad, O. Al-Mefty and S. Abdulrauf, "Meningiomas,” In: R. H. Winn, Ed., Youmans Neurological Surgery, Elsevier, Philadelphia, 2004, pp. 1099-1128.

[27] M. Lei and B. K. Tye, "Initiating DNA Synthesis: From Recruiting to Activating the MCM Complex," Journal of Cell Science, Vol. 114, No. 8, 2001, pp. 1447-1454.

[28] I. T. Todorov, B. A. Werness, H. Q. Wang, L. N. Buddharaju, P. D. Todorova, H. K. Slocum, J. S. Brooks and J. A. Huberman, "HsMCM2/BM28: A Novel Proliferation Marker for Human Tumors and Normal Tissues," Laboratory Investigation, Vol. 78, No. 1, 1998, pp. 7378.

[29] E. Jouanneau, “Angiogenesis and Gliomas: Current Issues and Development of Surrogate Markers," Neurosurgery, Vol. 62, No. 1, 2008, pp. 31-52. doi:10.1227/01.NEU.0000311060.65002.4E

[30] A. Lebelt, J. Dzieciol, K. Guzinska-Ustymowicz, D. Lemancewicz, L. Zimnoch and E. Czykier, “Angiogenesis in Gliomas,” Folia Histochemica et Cytobiologica, Vol. 46, No. 1, 2008, pp. 69-72. doi:10.2478/v10042-008-0009-4

[31] R. O. Barnard, "The Development of Malignancy in Oligodendrogliomas," The Journal of Pathology and Bacteriology, Vol. 96, No. 1, 1968, pp. 113-123.

doi:10.1002/path.1700960112
[32] G. C. Netto, C. B. Bleil, A. Hilbig and L. M. Coutinho, "Immunohistochemical Evaluation of the Microvascular Density through the Expression of TGF-Beta (CD 105/Endoglin) and CD 34 Receptors and Expression of the Vascular Endothelial Growth Factor (VEGF) in Oligodendrogliomas,” Neuropathology, Vol. 28, No. 1, 2008, pp. 17-23. doi:10.1111/j.1440-1789.2007.00825.x

[33] R. P. Shah, M. E. Leavens and N. A. Samaan, "Galactorrhea, Amenorrhea, and Hyperprolactinemia as Manifestations of Parasellar Meningioma," Archives of Internal Medicine, Vol. 140, No. 12, 1980, pp. 1608-1612. doi:10.1001/archinte.1980.00330230054014

[34] J. Kolodny and R. G. Dluhy, "Recurrent Prolactinoma and Meningioma Following Irradiation and Bromocriptine Treatment," The American Journal of Medicine, Vol. 78, No. 1, 1985, pp. 153-155. doi:10.1016/0002-9343(85)90477-2

[35] K. C. McCowen, J. N. Glickman, P. M. Black, N. T. Zervas, H. G. Lidov and J. R. Garber, "Gangliocytoma Masquerading as a Prolactinoma. Case Report," Journal of Neurosurgery, Vol. 91, No. 3, 1999, pp. 490-495. doi:10.3171/jns.1999.91.3.0490

[36] I. P. Santosh and V. Rajshekhar, "Galactorrhea as the Sole Presenting Symptom of a Posterior Third Ventricular Epidermoid Cyst," Surgical Neurology, Vol. 55, No. 1, 2001, pp. 46-49. doi:10.1016/S0090-3019(00)00351-7

[37] I. Fernandez, P. Touraine and V. Goffin, "Prolactin and Human Tumourogenesis," Journal of Neuroendocrinology, Vol. 22, No. 7, 2010, pp. 771-777.

[38] E. Tallet, V. Rouet, J. B. Jomain, P. A. Kelly, S. Bernichtein and V. Goffin, "Rational Design of Competitive Prolactin/Growth Hormone Receptor Antagonists,” Journal of Mammary Gland Biology and Neoplasia, Vol. 13, No. 1, 2008, pp. 105-117. doi:10.1007/s10911-008-9066-8

[39] M. Llovera, C. Pichard, S. Bernichtein, S. Jeay, P. Touraine, P. A. Kelly and V. Goffin, "Human Prolactin (hPRL) Antagonists Inhibit hPRL-Activated Signaling Pathways Involved in Breast Cancer Cell Proliferation,” Oncogene, Vol. 19, No. 41, 2000, pp. 4695-4705. doi:10.1038/sj.onc.1203846 